\title{
KURIKULUM PENDIDIKAN INKLUSI DI MASA PANDEMI DITINJAU DARI EVALUASI PROGRAM PEMBELAJARAN
}

\author{
Budi Dyah Lestari, Soraya Rosna Samta, Hanifatun Nisak, Sri Setiyo Rahayu \\ Prodi PJJ Pendidikan Guru Pendidikan Anak Usia Dini, Fakultas Keguruan dan Ilmu \\ Pendidikan, Universitas IVET, Indonesia
}

\section{Info Articles}

Sejarah Artikel:

Disubmit 28 Januari 2022

Direvisi 30 Januari 2022

Disetujui 2 Februari 2022

\section{Keywords:}

Evaluation of education

Program, inclusive education, CIPP model

\begin{abstract}
Abstrak
Tujuan dari penelitian ini adalah untuk menganalisis dan mendeskripsikan kurikulum inklusi yang diselenggarakan di PAUD Talenta Semarang, yang meliputi perencanaan, pengorganisasian, pelaksanaan dan evaluasi.). Pendidikan inklusi yang ada di PAUD Talenta Semarang adalah layanan PAUD yang memberikan kesempatan pada peserta didik yang memiliki kelainan dan memiliki potensi kecerdasan dan/atau bakat istimewa untuk mengikuti pendidikan atau pembelajaran dalam lingkungan pendidikan secara bersamasama dengan peserta didik pada umumnya. Informasi mengenai implementasi PAUD inklusi diungkap melalui metode wawancara terfokus, observasi dan dokumentasi sebagai teknik pengumpulan data. Ada tiga prosedur analisis data kualitatif dalam penelitian ini yaitu reduksi data, penyajian data dan penarikan kesimpulan. Model evaluasi yang digunakan adalah model CIPP. Hasil penelitian: (1) Evaluasi Context, pemerataan akses pendidikan di PAUD Talenta adalah pemenuhan kebutuhan orang tua dan ABK; semua ABK mampu terlayani; serta masyarakat memberikan kepercayaan penuh kepada sekolah dalam melayani ABK. (2) Evaluasi Input, meliputi unsur penilaian terhadap potensi sekolah, perencanaan program, anggaran, dan sumber daya manusia. (3) Evaluasi Prosees, pengawasan sekolah yang meliputi pemantauan, supervisi, evaluasi, pelaporan, tindak lanjut hasil pengawasan, dilakukan oleh kepala sekolah (yang berperan juga sebagai psikolog dan penanggungjawab supervisi) dan pendidik. (4) Evaluasi Product terhadap penyelenggaraan program pendidikan inklusi di PAUD Talenta Semarang berupaya untuk melakukan penilaian terhadap dampak penyelenggaraan program terhadap perkembangan peserta didik.
\end{abstract}

\section{Abstract}

The purpose of this study was to analyze and to describe the inclusion curriculum held in (Early Childhood Education) PAUD Talenta Semarang, which included planning, organizing, implementing and evaluating. Inclusive education is an innovative and strategic educational approach to broadering acceess to education for all children with special needs. Inclusive education in PAUD Talenta Semarang is a PAUD service that provides opportunities for students who have abnormalities and have the potential for intelligence and / or special talents to attend education or learning in an educational environment together with students in general. Information about the implementation of inclusive PAUD was revealed through focused interview methods, observation, and documentation as data collection techniques. There were three procedures for qualitative data analysis in this study, namely data reduction, data presentation, and drawing conclusion. The evaluation model used in this study was the CIPP model. The results of the study were: (1) The evaluation of Context, equitable access to education in PAUD Talenta was the fulfillment of the needs of parents and $\mathrm{ABK}$; all $\mathrm{ABK}$ were able to be served; and the community has given full trust to the school in serving ABK. (2) The evaluation of Inputs, including elements of an assessment of school potential, program planning, budget, and human resources. (3) The evaluation of Process, school supervision which includes monitoring, supervising, evaluation, reporting, following-up to the results of supervision, was carried out by principals (who also plays a role as a psychologist and supervising supervisor) and educators. (4) The evaluation of Product of the implementation of inclusive education programs in PAUD Talenta Semarang seeks to assess the impact of the program implementation on student development.

\footnotetext{
Alamat Korespondensi:

E-mail: alamat@email.mu
} 


\section{PENDAHULUAN}

Setiap anak memiliki karakteristik perkembangan yang berbeda-beda. Pemahaman terhadap anak perlu berangkat dari pemahaman pada setiap anak adalah unik dengan berbagai karakteristiknya. Vakil (2009), menyatakan Pendidikan inklusi adalah pendidikan bagi semua orang tanpa terkecuali termasuk anak berkebutuhan khusus (ABK). Hambatan yang paling sering muncul pada Anak Berkebutuhan Khusus dalam mengembangkan diri dan meraih sukses, termasuk dalam mengakses pendidikan setinggi mungkin bukan pada kecacatannya, tetapi pada penerimaan sosial masyarakat. Pendidikan inklusi yang diadakan di sekolah-sekolah umum di Indonesia masih merupakan hal baru, karena yang selama ini kita kenal, pendidikan untuk ABK adalah berada dalam Sekolah Luar Biasa (SLB). Perkembangan jaman dan kecenderungan negara-negara di dunia yang menghendaki adanya Education For All (pendidikan untuk semua) yang menghendaki agar setiap anak, termasuk ABK mendapatkan akses seluas-luasnya dalam bidang pendidikan. Sementara, Ahsan (2014) mendefinisikan, bahwa "pendidikan inklusi sekarang dianggap sebagai strategi yang layak untuk menciptakan pembelajaran lingkungan yang ramah untuk anak-anak/penyandang cacat, anakanak dari etnis yang berbeda dan keragaman bahasa, anak-anak yang berasal dari latar belakang yang kurang beruntung secara sosial dan juga isu-isu gender". Hal ini sejalan dengan pendapat Suparno (2010:2) meneliti tentang pendidikan inklusi untuk anak usia dini menyimpulkan bahwa konsep pendidikan untuk semua memang telah membuka kesadaran dan wawasan akan pentingnya pendidikan inklusi.

Penelitian yang dilakukan oleh Milena (2013: 50) menyimpulkan bahwa "dalam meningkatkan daya saing, suatu lembaga perlu melakukan inovasi di bidang manajemen dan bisnis, dan perlu menyediakan sumber daya yang cukup untuk menjawab tantangan tersebut". Hal ini menyiratkan bahwa suatu lembaga dapat meningkatkan daya saingnya, maka dibutuhkan inovasi dan perubahan dalam bidang manajemennya, dan semua sumber daya yang ada dalam lembaga tersebut harus dikelola dengan baik. Pengelolaan yang baik menyebabkan aktivitas suatu lembaga dapat lebih teratur, terpantau dan terkendali dengan baik, sehingga tujuan yang diharapkan dapat tercapai.

Ishartiwi (2010), dalam penelitiannya menyatakan bahwa pendidikan inklusi sebagai suatu sistem layanan anak berkebutuhan khusus menyatu dalam layanan pendidikan formal. Konsep ini menunjukkan hanya ada satu sistem pembelajaran dalam sekolah inklusi, tetapi mampu mengakomodasi perbedaan kebutuhan belajar setiap individu. Penyelenggara pendidikan inklusif memerlukan layanan pembelajaran sebanyak variasi kondisi anak berkebutuhan khusus. Variasi layanan tersebut perlu diikuti dengan dukungan sumber daya sarana belajar dan sumner daya pendidik serta sekolah yang mampu memberikan layanan anak berkebutuhan khusus. Aspek penting lainnya yang harus disiapkan adalah sistem evaluasi belajar. Dalam pendidikan inklusi selayaknya diterapkan sistem evaluasi reguler, evaluasi modifikasi, dan evaluasi individual. Implementasi pendidikan inklusi memerlukan perubahan manajemen sistem persekolahan dan komitmen bagi pelaku pendidik dan tingkat pengambil kebijakan dan praksis.

Kurikulum memiliki kedudukan yang sangat strategis, karena kurikulum disusun untuk mewujudkan tujuan pendidikan. Melalui kurikulum, sumber daya manusia dapat diarahkan dan kemajuan suatu bangsa akan ditentukan. Kurikulum harus dikembangkan sesuai dengan tahap perkembangan peserta didik, kebutuhan pembangunan nasional serta pengembangan ilmu pengetahuan dan tehnologi. Kurikulum pendidikan inklusi pada dasarnya menganut fleksibel kurikulum, dimana kurikulum disesuaikan dengan kebutuhan masing-masing peserta didik, dan dibuat dengan karakteristik dari sekolah penyelenggara itu sendiri, tanpa mengesampingkan pedoman yang telah ada. Pengembangan dan pelaksanaan kurikulum pendidikan inklusi itu sendiri hendaknya menumbuhkan kemandirian, kritis, dan dapat membangkitkan nilai-nilai kebersamaan dalam lingkungan sekolah. 
Beberapa model kurikulum dalam setting pendidikan inklusi antara lain: (1) Duplikasi, yaitu kurikulum untuk ABK disamakan dengan kurikulum umum, (2) Modifikasi, yaitu kurikulum umum yang diubah untuk disesuaikan dengan kebutuhan dan kemampuan ABK, (3) Substitusi, yaitu beberapa bagian dari kurikulum umum ditiadakan tetapi diganti dengan sesuatu yang kurang lebih setara, (4) Omisi, yaitu beberapa bagian dari kurikulum umum ditiadakan sama sekali karena tidak memungkinkan bagi ABK.

Evaluasi pelaksanaan kurikulum tidak hanya mengevaluasi hasil belajar peserta didik dan proses pembelajarannya tetapi juga rancangan dan pelaksanaan kurikulum, kemampuan dan kemajuan peserta didik, saran dan prasarana, serta sumber belajarnya. Substansi komponen CIPP dijelaskan bahwa evaluasi konteks berupaya mengidentifikasi kebutuhan yang mendasar pembuatan program; evaluasi input mengidentifikasi program, SDM, sarpras, pembiayaan, prosedur kerja, dan perencanaan; evaluasi proses menilai wujud program, pelaksana, waktu pelaksanaan dan anggaran; dan evaluasi produk menilai dampak program.

Model evaluasi yang digunakan adalah model CIPP. Hasil evaluasi dalam penelitian ini dipaparkan dan digambarkan dalam bentuk kalimat, keterangan atau pernyataan bermakna terhadap penyelenggaraan program pendidikan inklusi di PAUD Talenta Semarang. Subyek atau informan dalam penelitian ini mencakup kepala sekolah, guru, dan orang tua murid. Dalam penelitian ini, data dikumpulkan dan diperoleh melalui tehnik wawancara dan studi dokumentasi. Wawancara dilakukan dengan kepala sekolah, guru dan oranng tua siswa. Oleh karena itu guru perlu adanya inovasi pembelajaran yang efektif sehingga mampu meningkatkan kualitas pembelajaran sekolah. Melalui kurikulum pendidikan inklusi diharapkan mampu menjadi umpan balik dan tindak lanjut untuk meningkatkan mutu pendidikan yang diselenggarakan.

\section{METODE}

Jenis penelitian ini menggunakan metode kualitatif dengan pendekatan studi kasus desain kasus tunggal terjalin. Metode kualitatif ini dipilih dengan tujuan untuk memperoleh data secara komprehensif, sebagai sumber data langsung mengenai segala sesuatu yang berkaitan dengan tentang evaluasi program kurikulum pendidikan inklusi pada PAUD Talenta Semarang. Model evaluasi yang digunakan adalah model CIPP.

Dengan adanya perbedaan dari beberapa model evaluasi, maka model evaluasi yang dapat menjadi pertimbangan peneliti dalam melakukan evaluasi ini adalah CIPP (Context - Input - Process Product) yang dikembangkan oleh Daniel Stuffleabem, dkk (1967) di Ohio state University. Hasil evaluasi dalam penelitian ini dipaparkan dan digambarkan dalam bentuk kalimat, keterangan atau pernyataan bermakna terhadap penyelenggaraan program pendidikan inklusi di PAUD Talenta Semarang.

Tehnik yang digunakan untuk pengumpulan data dalam penelitian ini adalah observasi, wawancara, dan studi dokumen. Sugiyono (2013:378) mengatakan bahwa dalam observasi partisipasif ini, peneliti terlibat dalam kegiatan sehari-hari orang yang sedang diamati atau yang digunakan sebagai sumber data penelitian. Tujuan wawancara adalah untuk mengetahui hal-hal yang mendalam tentang partisipan dalam menginterprestasikan situasi dan fenomena yang terjadi dalam evaluasi kurikulum pendidikan inklusi dan hal ini tidak bisa ditemukan melalui observasi (Sugiyono, 2012:318). Dokumen bisa berbentuk tulisan, gambar, atau karya-karya monumental dari seseorang. Menurut Sugiyono (2010:329) studi dokumen merupakan pelengkap dari penggunaan metode observasi dan wawancara dalam penelitian kualitatif. Hasil penelitian dari observasi dan wawancara, akan lebih dapat dipercaya kalau didukung oleh sejarah pribadi sekolah dan foto-foto atau karya tulis akademik. 


\section{HASIL DAN PEMBAHASAN}

Pengembangan kurikulum PAUD inklusi yang disusun oleh PAUD Talenta mengacu pada kurikulum PAUD yang ditetapkan pemerintah. Kurikulum untuk anak berkebutuhan khusus merupakan kurikulum PAUD yang dimodifikasi sesuai dengan potensi dan kebutuhan anak. Pengelolaan kurikulum dikelola sesuai dengan fungsi-fungsi pengelolaan, yaitu: perencanaan, pelaksanaan, pengorganisasian, dan pengevaluasian. Agar kurikulum yang baik dapat tercapai, harus diimplementasikan dengan baik, kreatif, dan inovatif. Untuk dapat mengetahui tingkat tersebut harus melewati satu tahap yang dinamakan evaluasi kurikulum. Kegiatan perencanaan kurikulum pendidikan inklusi dilaksanakan dalam beberapa tahapan yaitu, penetapan visi, misi dan tujan, identifikasi kebutuhan kurikulum, penyususnan kurikulum peserta didik, perencanaan pengelolaan kelas inklusi, dan evaluasi perencanaan.

PAUD Talenta Semarang juga melakukan tahapan tersebut dalam proses perencanaan kurikulum pendidikan inklusi. Proses perencanaan kurikulum yang dimulai dari identifikasi kurikulum tersebut dilaksanakan pada awal bulan Juli, dalam suatu pertemuan yang diadakan oleh pihak sekolah, yang dihadiri oleh Kepala Sekolah, Guru, orang tua siswa dan juga komite sekolah. Setelah proses analisis kebutuhan kurikulum dilaksanakan, kemudian dirumuskan konsep kurikulum sekolah untuk anak reguler dan juga konsep kurikulum untuk anak inklusi, atau kurikulum yang dimodifikasi. Penetapan konsep kurikulum itu sendiri dilaksanakan dalam sebuah rapat dan hasil penetapan tersebut disebut dengan dokumen kurikulum.

Berdasarkan hasil penelitian, proses perencanaan kurikulum pendidikan inklusi di PAUD Talenta Semarang sesungguhnya telah dilakukan dengan baik, dan sesuai dengan kebutuhan siswa siswinya, disesuaikan dengan potensi dan keterbatasan yang ada. Hal ini sejalan dengan penelitian yang dilakukan oleh Maharani (2015), bahwa pembelajaran harus bersifat interaktif yang berbasis pada kurikulum 2013. Kurikulum yang telah disusun bersama melalui rapat pleno, bertujuan memberdayakan semua yang terlibat dalam pengelolaan program.

Proses manejemen dalam pelaksanaan kurikulum PAUD Talenta Semarang melibatkan berbagai pihak yang terkait dengan membagi tugas dan wewenang masing-masing. Dalam mengatur terlaksananya kurikulum, telah dilakukan koordinasi dan kerjasama secara internal yaitu antara kepala sekolah dengan guru dan secara eksternal yaitu antara pihak sekolah dengan orang tua siswa. Dalam kebijakan pengembangan kurikulum, guru dituntut untuk dapat berperan serta dan bisa memahami isi dari kurikulum tersebut, karena akan berdampak dalam kegiatan belajar mengajar sehari-hari. Pelaksanaan kurikulum pendidikan inklusi di PAUD Talenta Semarang berkenaan dengan kegiatan pembelajaran yang mencakup penyusunan program pembelajaran, pelaksanaan kegiatan belajar mengajar dan metode pembelajaran yang dipakai, model pengelolaan kelas, dan evaluasi pembelajaran. Pembelajaran dalam pendidikan inklusi mempertimbangkan prinsip-prinsip pembelajaran yang disesuaikan dengan kemampuan dan kebutuhan peserta didik. Pelaksanaan pembelajaran kelas inklusi di PAUD Talenta Semarang dilakukan dengan metode demonstratif dan ramah terhadap semua peserta didik.

Berdasarkan hasil penelitian di lapangan pelaksanaan kurikulum anak berkebutuhan khusus di PAUD Talenta Semarang telah mengorganisasikan sumber daya manusia, sarana dan prasarana. Dalam mengatur terlaksananya kurikulum, telah dilakukan koordinasi dan kerjasama secara internal yaitu antara kepala sekolah dengan guru dan secara eksternal yaitu antara pihak sekolah dengan orang tua siswa. Evaluasi pelaksanaan kurikulum inklusi di PAUD Talenta Semarang ini dilakukan kepala sekolah dan guru-guru setiap hari, setelah proses pembelajarn peserta didik berakhir. Dalam evaluasi ini, guru-guru menyampaikan pembelajaran yang telah dilakukan hari itu, juga hambatan yang ada dan secara bersama-sama mencari solusinya. Penelitian dari Herman dan Shantz (1983:217-226) 
menyatakan bahwa orangtua yang secara matang mengakui, beradaptasi dan menerima kenyataan mengenai ketidakmampuan anak akan membawa keuntungan, terutama pada perkembangan interaksi sosial dan komunikasi ABK. Pengorganisasian kurikulum pendidikan inklusi yang ada di PAUD Talenta Semarang dilaksanakan dengan mengorganisasikan seluruh sumber daya manusia, sarana dan prasarana, koordinasi dan kerjasama dengan berbagai pihak. Proses pengorganisasian dalam kurikulum inklusi dilakukan oleh Kepala Sekolah dengan cara membagi tugas dan wewenang pada guru kelas dan guru pendamping khusus, dan ini dilakukan setelah adanya perencanaan kurikulum pendidikan inklusi, yang biasanya dilakukan sebelum tahun ajaran baru.

Dengan melihat proses pengorganisasian dan koordinasi yang telah dilakukan oleh Kepala Sekolah di PAUD Talenta Semarang sesungguhnya telah dilakukan pengorganisasian sumber daya manusia dengan baik dalam rangka melaksanakan kurikulum pendidikan inklusi. Pengorganisasian dalam implementasi kurikulum pendidikan inklusi di PAUD Talenta Semarang dilakukan dengan mengerahkan seluruh sumber daya yang ada, terutama dalam hal ini sumber daya manusia dan mengkoordinasinya. Dalam pengorganisasian kurikulum pendidikan inklusi ini, kepala sekolah memilih orang-orang yang telah memiliki kemampuan dalam mengelola pendidikan inklusi, terutama dalam pelaksanaannya.

Evaluasi kurikulum berfungsi untuk memberikan informasi dan pertimbangan yang berkenaan dengan ketercapaian suatu program, kesesuaian materi dan bahan ajar, dan evaluasi proses kegiatan belajar mengajar yang berguna untuk memperbaiki kurikulum yang telah digunakan. Evaluasi merupakan upaya kontrol terhadap semua komponen kelembagaan dalam merealisasikan programprogram pembelajaran, dan bersifat memotivasi, memberi pengarahan, dan membantu memecahkan masalah serta kendala yang terjadi di lapangan, sehingga program dapat berjalan dengan lancar.

Kegiatan evaluasi kurikulum pendidikan inklusi di PAUD Talenta Semarang meliputi evaluasi terhadap kinerja guru, administrasi guru, dan program pendidikan inklusi sudah dilaksanakan dengan baik, penggunaan sarana dan prasarana dan media pembelajaran sudah maksimal. Berikut gambaran tentang proses evaluasi kurikulum di PAUD Talenta Semarang.

Model CIPP dianggap sesuai dengan kajian evaluasi penyelenggaraan program pendidikan inklusi dengan beberapa pertimbangan. Pertama, model ini memiliki langkah-langkah yang jelas dalam mengungkapkan setiap urutan program. Kedua, penulis dapat menganalis secara detail mulai dari hal yang melatarbelakangi penyelenggaraan program (context), bentuk perencanaan program (input), pelaksanaan program (prosess) dan produk yang dihasilkan dari penyelenggaraan program (product). Akhir dari evaluasi akan memberikan rekomendasi atas keberadaan program. Oleh karena itu, penyelenggaraan program pendidikan inklusi di PAUD Talenta Semarang dievaluasi dengan menggunakan model CIPP.

\section{Hasil Evaluasi Kurikulum Pendidikan Inklusi PAUD Talenta Semarang}

\section{Evaluasi Context}

Evaluasi context terhadap penyelenggaraan pendidikan inklusi di PAUD Talenta Semarang meliputi unsur penilaian terhadap kebutuhan yang belum terpenuhi, populasi yang dilayani, dan peluang atau manfaat dari penyelenggraan program. Berdasarkan hasil temuan dari semua aspek pada komponen context terhadap penyelenggaraan program inklusi di PAUD Talenta Semarang, pemerataan akses pendidikan di yayasan Talenta adalah pemenuhan kebutuhan orang tua dan ABK sudah terlayani dengan maksimal, semua ABK dengan jenis kebutuhan khusus ringan hingga sedang mampu terlayani, serta masyarakat atau sosial memberikan kepercayaan penuh kepada sekolah dalam melayani ABK. Hasil temuan ini sesuai dengan hasil penelitian yang dilakukan Isabella dkk. (2014) dimana implementasi pendidikan inklusi di PAUD Talenta Semarang sangat dibutuhkan masyarakat 
sekitar karena adanya keinginan dan kebutuhan sekolah untuk menyekolahkan anaknya yang memiliki kebutuhan khusus di sekolah reguler.

Pada komponen context terhadap populasi yang dilayani adalah peserta didik dengan kebutuhan khusus dan berpotensi pada kecerdasan dan/atau bakat istimewa, yang direkrut dengan prioritas pada jarak terdekat domisili anak ke sekolah. Dengan penerimaan peserta didik berkebutuhan khusus, sekolah mendapat manfaat atas kepercayaan dan apresiasi yang diberikan oleh masyarakat khususnya orang tua $\mathrm{ABK}$ terhadap pelaksanaan program pendidikan inklusi. Penelitian yang dilakukan oleh Olson (2003, 13-15) mengkaji tentang sikap guru terhadap pendidikan inklusi. Guru dalam mengimplementasikan kurikulum ada yang memiliki gambaran positif atau negatif tentang $A B K$. Sikap dan komitmen guru dalam mengembangkan ABK yang menjadi tanggungjawab guru juga menggambarkan sejauh mana $A B K$ diterima di sebuah sekolah. Melalui sikap positif dari guru, $A B K$ akan mendapat lebih banyak kesempatan dalam bidang pendidikan untuk belajar dengan teman sebayanya, dan akan lebih mendapatkan keuntungan pendidikan semaksimal mungkin.

\section{Evaluasi Input}

Evaluasi input terhadap penyelenggaraan program pendidikan inklusi di PAUD Talenta Semarang meliputi unsur penilaian terhadap potensi sekolah, perencanaan program, anggaran, dan sumber daya manusia. Dalam pelaksanaan program, sarana dan prasarana sebagai pendukung program di PAUD Talenta Semarang memiliki ketersediaan yang bervariasi. Hasil penelitian menunjukkan bahwa sekolah ini masih mengandalkan sarana prasarana yang sudah dimiliki sebelumnya. Sarpras ini umumnya digunakan secara merata baik siswa reguler maupun ABK. Selain itu, sekolah belum didukung dengan prasarana yang memadai seperti ruang atau kelas khusus guna melayani ABK secara individual.

Di sisi lain, pelaksanaan program pendidikan inklusi melibatkan pihak di dalam maupun diluar sekolah. Hasil penelitaian menenjukkan bahwa PAUD Talenta Semarang melibatkan pihak dalam sekolah yaitu Kepala Sekolah, Komite, Wakasek, dan Guru. Hasil temuan ini sesuai dengan penelitian Danarhadi (2017) bahwa salah satu prisip keterlibatan, dimana penyelenggaraan pendidikan inklusi harus melibatkan seluruh komponen pendidikan terkait. Sementara keterlibatan dari pihak luar sekolah berupa bantuan dan kerja sama dengan pihak terkait lainnya

Sumber dana dalam pelaksanaan program pendidikan inklusi diperoleh dari dana BOS. Hasil temuan ini sudah sesuai dengan kriteria penyelenggraan pendidikan inklusi bahwa sumber pendaanan penyelenggaraan program ini diperoleh dari dana pemerintah atau sumber lain yang sah dan tidak mengikat.

Sementara dalam hal sumber daya manusia (SDM) yaitu guru pendamping khusus (GPK), di PAUD Talenta Semarang belum memiliki GPK yang berlatar belakang pendidikan khusus atau pendidikan luar biasa. Terkait penemuan ini, penanganan ABK di sekolah ini masih ditangani oleh Guru masing-masing kelas. Guru-guru dalam situasi tersebut dianggap sebagai "GPK" versi sekolah masing-masing. Peran guru dan guru pendamping bagi ABK memang sangat menentukan keberhasilan implementasi kurikulum. Hasil ini sejalan dengan penelitian yang dilakukan oleh Avramidis dan Norwich (2002:129-147) yang menyatakan bahwa guru lebih mendukung program inklusi untuk ABK yang telah mampu bersekolah dan mengikuti pelajaran. Sedangkan ABK yang kurang mampu mengikuti pelajaran diperlukan pendamping dalam belajar dan terapis untuk mempermudah guru menangani $\mathrm{ABK}$.

Sebagian guru kelas dan wali kelas di PAUD Talenta Semarang pernah mendapatkan workshop, diklat, sosialisasi dan/atau pelatihan khusus untuk meningkatkan kompetensi. Temuan ini sesuai dengan Permendiknas No. 70 Tahun 2009 pasal 10 ayat 3, 5, dan 6 yang menjelaskan bahwa "pemerintah kabupaten/kota wajib meningkatkan kompetensi di bidang pendidikan khusus bagi tenaga pendidik dan tenaga kependidikan pada satuan pendidikan penyelenggara pendidikan inklusi".

\section{Evaluasi Prosess}


PAUD Talenta Semarang, melakukan proses sesuai prosedur, dimana pengawasan sekolah yang meliputi pemantauan, supervisi, evaluasi, pelaporan, tindak lanjut hasil pengawasan, dilakukan oleh kepala sekolah dan pendidik. Dalam proses pembelajaran di dalam kelas, hasil temuan menunjukkan bahwa guru di PAUD Talenta Semaraang memiliki kompetensi yang cukup memadai. Hal ini terbukti dari penyusunan RPP, pemberian materi dan bahan ajar kepada ABK dengan menggunakan kurikulum dan materi/bahan ajar yang sama atau reguler.

Pemberian materi dan bahan ajar kepada ABK dengan menggunakan kurikulum dan materi/bahan ajar yang sama atau reguler. Guru tidak memberikan atau membedakan kurikulum dan materi/bahan ajar secara terstruktur. Selain itu guru menggunakan RPP reguler yang diberikan secara merata kepada semua siswa. Akan tetapi karena ragam hambatan ABK sangat bervariasi, baik bersifat ringan hingga sedang, maka dalam implementasinya harus ada modifikasi kurikilum tingkat satuan pendidikan yang sesuai dengan standart nasional dan kebutuhan ABK.

Hal ini sesuai dengan penelitian Nasution (2017) yang menyatakan kurikulum yang digunakan adalah kurikulum tingkat satuan pendidikan yang mengakomodasi kebutuhan dan kemampuan ABK sesuai bakat, minat, dan potensinya. Terkait dengan itu hasil penelitian menunjukkan bahwa PAUD Talenta Semarang melakukan modifikasi kurikulum melalui pemberian atau pelayanan pendidikan pada siswa kebutuhan khusus.

Berdasarkan hasil penelitian, selain proses belajar di kelas, PAUD Talenta Semarang juga menyiapkan dan membuka kegiatan ekstrakuriluler yang juga diberikan kepada ABK. Siswa ABK diberi kebebasan untuk memilih kegiatan ekstrakurikuler yang tersedia sesuai bakat, minat, kemampuan, dan ketertarikan $\mathrm{ABK}$ itu sendiri.

\section{Evaluasi Product}

Evaluasi pruduct terhadap penyelenggaraan program pendidikan inklusi di PAUD Talenta Semarang berupaya untuk melakukan penilaian terhadap dampak penyelenggaraan program terhadap perkembangan peserta didik. Perkembangan ABK baik dari segi akademik maupun non akademik disesuiakan dengan jenis kebutuhan khusus/kelainan ABK.

PAUD Talenta Semarang dengan jenis kebutuhan yang bervariasi memiliki perkembangan prestasi yang baik dan perkembangan non akademik yang baik bahkan membagakan sekolah. Peserta didik berkebutuhan khusus mampu mencapai nilai standart sesuai standart tingkat pencapaian perkembangan anak yang telah dimodifikasi oleh lembaga sekolah. Hasil temuan ini sejalan dengan penelitian Widyawati (2017) yang menyatakan prestasi akademik dan non akademik anak berkebutuhan khusus dengan hasil yang bervariasi ditentukan dari tingkat kemampuan siswa masingmasing.

\section{SIMPULAN}

Berdasarkan hasil penelitian dan pembahasan diatas, maka simpulan penelitian adalah Dari segi contecxt, pelaksanaan program pendidikan inklusi di PAUD Talenta Semarang dimaksudkan untuk memenuhi kebutuhan yang belum terpenuhi, yaitu permintaan orang tua $A B K$ untuk menyekolahkan anak mereka di sekolah regular mampu terlayani dengan baik, serta masyarakat memberikan kepercayaan kepada PAUD Talenta Semarang dalam melayani ABK.

Dari segi input, pelaksanaan program pendidikan inklusi di PAUD Talenta Semarang sudah menunjukkan bahwa ketersediaan sarpras umum sudah memenuhi kebutuhan semua siswa walau ketersediaan sarpras khusus bagi ABK belum memadai. Pelaksanaan program pendidikan inklusi juga sudah cukup dibiayai baik dari alokasi dana BOS maupun APBD. Namun PAUD Talenta Semarang belum memiliki GPK sehingga ABK ditangani oleh guru umum/reguler.

Berdasarkan evaluasi terhadap komponen process. Dinas terkait baru pertama kali melakukan pengawasan melalui monitoring dan evaluasi sekolah. Kompetensi guru cukup memadai dalam 
menangani layanan individual bagi para $\mathrm{ABK}$. Selain itu, terdapat kegiatan ekstrakurikuler yang diperuntukan bagi ABK. Masalah atau kendala yang ditentukan adalah tidak adanya GPK, sarpras khusus belum memadai, pelatihan khusus bagi guru, belum ada monitoring lebih lanjut dari Dinas terkait, dan tidak ada standart baku dalam penilaian hasil belajar.

Dari segi product, dampak pelaksanaan program terletak pada pencapaian prestasi ABK dan jumlah ABK yang terlayani. Perkembangan akademik (kognitif) dan non akademik (psikomotorik) ABK cukup baik. Sementara, jumlah ABK yang terlayani tergolong variatf dan semua ABK dilayani sekolah dengan penyesuaian terhadap keadaan dan kemampuan sekolah.

\section{DAFTAR PUSTAKA}

Ahsan, M. T. 2014. "Inclusive Education: A Strategy to Addres Diversity to Ensure Equal Right to Education. Editorial". Asian Journal of Inclusive Education (AJIE). 2(1), 1-3.

Avramidis, E., dan Norwich, B. 2002. Teachers Attitudes Towards Integration/Inclution: A Review of the Literature. European Journal of Special Needs Education. 17(2),129-147.

Danarhadi, F.H., 2017. Implementasi Kebijakan Pendidikan Inklusi Di Smp Ekakapti Karangmojo Gunung Kidul Yogyakarta. Spektrum Analisis Kebijakan Pendidikan, 6(5), 541-549.

Herman, M.S., dan Shantz, C.H. 1983. Social Problem Solving and Mother Child Interaction of Educable Mentally Retarded Children. Journal of Applied Developmental Psychologi. 4(3),217226.

Isabella, P., Emosda, E. and Suratno, S., 2014. Evaluasi Penyelenggaraan Pendidikan Inklusi Bagi Peserta Didik Berkebutuhan Khusus Di SDN 131/IV Kota Jambi. Jurnal Tekno-pedagogi, $4(2), 45-59$.

Ishartiwi, 2010. "Implementasi Pendidikan Inklusif Bagi anak Berkebutuhan khusus Dalam Sistem Prasekolah Nasional", JPK, 6(2), 11-19.

Maharani, Y. S. 2015. "Efektivitas Multimedia Pembelajaran Interaktif Berbasis Kurikulum 2013". Indonesian Journal of Curriculum and Educational Technology Studies IJCETS, 3(1), 70-76.

Milena, J. 2013, "Potensial Future Managers and Their Opinion On The Issue of Diversity, Inclution and Their Possible Use in Management", Journal of Competitiveness, 5(2), 50-55.

Nasution, A.K.P., 2017. Kurikulum Tingkat Satuan Pendidikan Berbasis Inklusi Di Taman KanakKanak. Jurnal As-Salam, 1(3), 90-97.

Olson, J.M. (2003). Special Education and General Education Teacher Attitudes Toward Inclusion. The Journal of Special Education. 6(3),15-17.

Permendiknas Nomor 70 Tahun 2009 Tentang Pendidikan Inklusif Bagi Peserta Didik yang Memiliki Kelainan dan Memiliki Potensi Kecerdasan dan/atau Bakat Istimewa.

Stufflebeam. L. Daniel, Shinkfield, J. Anthony. 2007. Evaluation Theory, Models \& Applications. San Fransisco: Jossey Bass.

Sugiyono, 2010, Metode Penelitian Pendidikan, Pendekatan Kuantitatif, Kualitatif, dan $R \& D$, Bandung: Alfabeta. 
Suparno. 2010. Pendidikan Inkluisi untuk Anak Usia Dini. Jurnal Pendidikan Khusus. 7(2), 1-17.

Vakil, S. 2009. "Inclusion Means Everyone: The Role Of The Early Childhood Educator When Including Young Children Autism In The Classroom". Early Childhood Education Journal, 5(1), 115-124.

Widyawati, R., 2017. Evaluasi Pelaksanaan Program Inklusi Sekolah Dasar. Kelola: Jurnal Manajemen Pendidikan, 4(1), 109-120. 